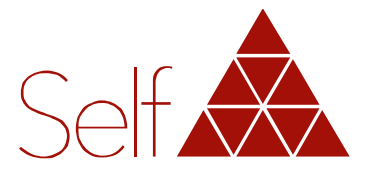

Revista do Instituto Junguiano de São Paulo

\title{
As deusas celtas e a jornada simbólica da alma feminina
}

\author{
Mayra Cristina Silva Faro CAVALCANTE
}

Belém, PA, Brasil.

*Este trabalho é derivado do monografia "As deusas celtas e jornada simbólica da alma feminina", defendida em 2019, no curdo de PósGraduação em Psicologia Analítica, da Faculdade Unyleya

Conflito de interesses: A autora declara não haver nenhum interesse profissional ou pessoal que possa gerar conflito de interesses em relação a este manuscrito.

\section{Resumo}

Este artigo visa a apresentar uma análise arquetípica dos mitos de cinco deusas da mitologia celta, que refletem aspectos simbólicos e profundos da alma feminina, contribuindo dessa forma com o processo terapêutico e de individuação das mulheres. As antigas histórias míticas, permeadas de símbolos, ressoam por milênios nas culturas humanas, no imaginário e no folclore. Observa-se nos antigos mitos celtas um vasto e profundo material simbólico sobre a psique humana. Ao contrário da mitologia greco-romana, que é bastante divulgada e foco de amplas pesquisas, a mitologia celta ainda é pouco investigada. Assim, este artigo intenta contribuir com os estudos sobre a mitologia celta, no campo da psicologia analítica, tecendo diálogos com as ciências das religiões e a fenomenologia. Para tanto, foram analisadas cinco deusas celtas: Danann, Brighid, Macha, Cailleach e Cerridwen. A abordagem do trabalho foi qualitativa e fenomenológica, com pesquisa bibliográfica, pautando-se nos estudos de C. G. Jung, Jacobi, Mircea Eliade, Clarissa P. Estés e outros.

\section{Descritores}

deusas, mitos, arquétipos, feminino.

Recebido: 5 fev 2020; 1ª revisão: 16 mar 2020; Aprovado: 24 abr 2020; Aprovado para publicação: 21 maio 2020 


\title{
The Celtic goddesses and the symbolic journey of the feminine soul
}

\begin{abstract}
This article presents an archetypal analysis of the myths of five goddesses of the Celtic mythology, which reflect symbolic and deep aspects of the feminine soul, contributing in this way to the therapeutic process and individuation of women. The ancient mythic stories, permeated by symbols, resound for thousands of years in human cultures, in the imaginary and the folklore. Ancient Celtic myths contain vast and profound symbolic material about the human psyche. However, unlike Greco-Roman mythology, which is well known and the focus of much research, Celtic mythology is still unexplored. For this reason, this article attempts to contribute to studies of Celtic mythology in the field of analytical psychology, weaving dialogues with religion sciences and phenomenology. To achieve this, five goddesses were analyzed, they are: Danann, Brighid, Macha, Cailleach and Cerridwen. This study's approach is qualitative and phenomenological, with bibliographical research, based on the studies of C. G. Jung, Jacobi, Mircea Eliade, Clarissa P. Estés and others.
\end{abstract}

\section{Descriptors}

goddesses, mithys, archetypes, feminine.

\section{Las diosas celtas y el viaje simbólico del alma femenina}

\section{Resumen}

Este ensayo tiene como objetivo presentar un análisis arquetípico de los mitos de cinco Diosas de la mitología celta, que reflejan aspectos simbólicos y profundos del alma femenina, contribuyendo así al proceso terapéutico y de individuación de las mujeres. Antiguas historias míticas, impregnadas de símbolos, resuenan durante milenios en las culturas humanas, en el imaginario y el folklore. En los antiguos mitos celtas, se observa un material simbólico vasto y profundo sobre la psique humana. Pero, a diferencia de la mitología grecorromana, que está ampliamente difundida y es objeto de amplios estudios, la mitología celta sigue siendo un campo poco estudiado. Por eso, este artículo pretende contribuir con los estudios de mitología Celta en el campo de la psicología analítica, tejiendo diálogos con las ciencias de las religiones y la fenomenología. Cinco diosas para se analizan en este estudio, y ellas son Danann, Brighid, Macha, Cailleach y Cerridwen. El enfoque de este 
trabajo es cualitativo y fenomenológico, con investigación bibliográfica, basada en los estudios de C. G. Jung, Jacobi, Mircea Eliade, Clarissa P. Estés y otros.

\section{Descriptores}

diosas, mitos, arquétipos femenino.

\section{Introdução}

Os mitos são a linguagem da alma. Eles expressam a origem das coisas, das culturas, da natureza, ritos e costumes, além de representarem aspectos e facetas da psique humana. Segundo Jung (1964/2016),

Por existirem inúmeras coisas fora do alcance da compreensão humana é que frequentemente utilizamos termos simbólicos como representação de conceitos que não podemos definir ou compreender integralmente. Esta é uma das razões por que todas as religiões empregam uma linguagem simbólica e se exprimem através de imagens (p. 19).

Os mitos surgem da intensa relação entre o sagrado e o profano (Eliade, 2012) e falam em linguagem simbólica, portanto, é necessário compreendêlos de forma subjetiva. De acordo com Leonardo Boff (2014),

Estimamos que as mitologias, mais que as ciências e as filosofias, encerram, junto com as religiões, os grandes elucidamentos [sic] da essência humana. Aí as culturas projetaram, geração após geração, grandes visões, acumularam reflexões, fizeram aprofundamentos e os passaram a seus pósteros. Souberam usar de uma linguagem plástica, com imagens tiradas das profundezas do inconsciente coletivo, acessível a todas as idades e a todos os tempos (p. 42).

Com isso, podemos perceber a importância de se conhecer os mitos, sua linguagem, seus símbolos e seu alcance na psique humana, seja como meio de autoconhecimento, seja como caminho para a abordagem terapêutica.

Muito se conhece sobre a mitologia greco-romana e mesmo sobre a egípcia dentro dos estudos acadêmicos. Mas, até o momento, há poucas referências (sobretudo na língua portuguesa) acerca da mitologia celta e suas implicações na psique e no imaginário humano. Assim, este artigo aborda os mitos celtas, em específico de cinco deusas, e como eles expressam arquétipos femininos e refletem importantes aspectos da jornada simbólica da mulher.

Para a psicologia junguiana ou psicologia profunda, os arquétipos são imagens primordiais que expressam modelos essenciais que compõem a psique humana e, conforme a cultura em que se apresentam, assumem diferentes roupagens. De acordo com Jung (1940/1951, p. 142, citado por Jacobi, 2016, p. 68): 
Nenhum arquétipo se deixa reduzir a uma fórmula simples. Ele é um recipiente que nunca podemos nunca [sic] esvaziar, nem encher. Ele existe em si apenas potencialmente, e se ele toma forma na matéria, ele não é mais o que era antes. Ele persiste através dos milênios e exige sempre nova interpretação.

Os mitos, símbolos e imagens são manifestações ou expressões do arquétipo que nunca se esgotam e estão sempre se reinventando, transformando-se a partir de novos olhares. Podemos afirmar que um dos arquétipos mais primordiais, senão o mais primordial deles, está relacionado ao princípio feminino. De acordo com Terrin (1996):

O feminino e o materno ocupam na história das religiões um lugar excepcionalmente grande, cheio de fascínio e de mistério. Basta voltar para a aurora da humanidade, além dos próprios mitos das origens, ou então a escavar em nosso inconsciente, terreno menos distante e impraticável, para encontrar as particulares figurações arquetípicas que delineiam seus traços (p. 190).

A ligação entre a mulher e tudo o que é mistério na natureza é bastante antiga. Originariamente, a mulher era considerada a representação da própria deusa "Terra", propiciadora da vida, da fertilidade, e ao mesmo tempo, conhecedora dos ciclos misteriosos da natureza, o que a conectava com o universo mágico e sagrado. Depois, ela passou a ser associada, de forma negativa, ao lado desconhecido e obscuro da realidade, transformando-se de sacerdotisa em feiticeira e mais tarde, no Medievo, em bruxa (Nogueira, 2004).

Os povos celtas reverenciavam diversas deusas e deuses como manifestações da natureza e de seus mistérios. Falavam línguas de origem indo-europeia, cujas variações hoje são o irlandês, o gaélico-escocês, o córnico, o galês e o bretão. Uma análise de evidências arqueológicas mostra a difusão de um povo nômade pela Europa, a partir do segundo milênio a.C., que se espalhou tanto em direção ao Ocidente quanto em direção ao Oriente. À medida que se estabeleciam, mesclavam-se com populações autóctones, cuja cultura remonta ao Paleolítico e, assim, deram origem a diversos povos da antiguidade (Launay, 1978).

A arte céltica é rica em símbolos de seu imaginário. Animais sagrados, deuses, deusas, guerreiros e formas em espirais revelam-nos aspectos importantes da cultura e da espiritualidade desses povos, como podemos ver no detalhe de um antigo artefato, encontrado na Dinamarca e datado do século I a.C. Essa imagem do Caldeirão de Gudenstrup (Figura 1) mostra, à direita, um deus segurando dois homens que oferecem animais e, à esquerda, uma deusa com pássaros emblemáticos, uma mulher (possivelmente uma sacerdotisa) trançando seu cabelo, outra mulher sentada de um lado e uma figura humana deitada próximo ao seio da deusa. 


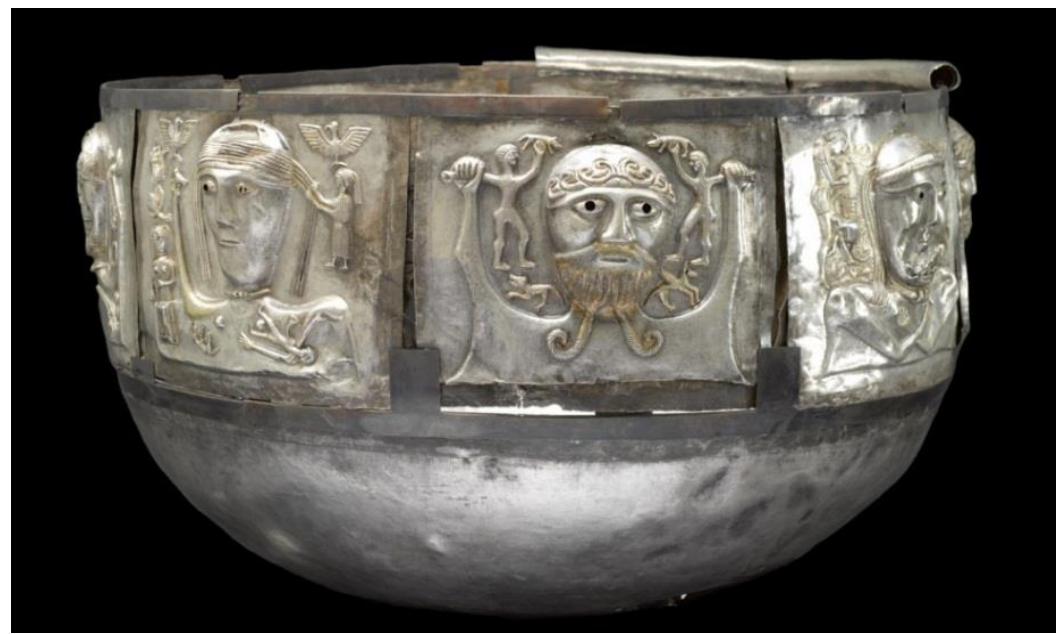

Figura 1. Detalhe do Caldeirão de Gudenstrup (reproduzido de: https://britishmuseum.tumblr.com/post/132087416007/the-gundestrup-cauldron. Acesso em 20/02/2019).

A religiosidade céltica é centrada no culto à natureza e nos ciclos agrícolas. Fenômenos astronômicos e a passagem das estações também eram reverenciados por eles, que enxergavam nesses aspectos a influência ou regência das divindades. Sua cultura apresenta uma forte característica animista, ou seja, a crença de que em tudo há alma (anima), de animais a florestas, rios, montanhas, astros e até objetos (Barros, 1994; Carr-Gomm, s.d.). Por todo o território céltico, encontramos lugares sagrados, círculos de pedras, colinas, rios e tumbas neolíticas.

Em vários mitos celtas encontra-se um elemento, isto é, um arquétipo central para a cultura e a religiosidade deste povo - tal arquétipo é o do feminino, representado na figura de uma deusa ou rainha que encarna os atributos da Terra e da soberania. Este artigo se propõe a analisar este arquétipo e suas facetas, a partir de cinco deusas.

Clarissa P. Estés (1997), analista junguiana, escritora e contadora de histórias, afirma que a "vitalidade esvaída das mulheres pode ser restaurada por meio de extensas escavações 'psíquico-arqueológicas' nas ruínas do mundo subterrâneo feminino" (p. 15). Em seu trabalho desenvolvido especialmente com mulheres, Estés (1997) utiliza a sabedoria profunda contida nos mitos e até mesmo em alguns contos de fada para fortalecer o processo de cura e a redescoberta da natureza mais profunda da mulher, denominada pela autora como arquétipo da "mulher selvagem".

Ao adentrarmos nos mitos das antigas deusas celtas, vamos compreendendo como os arquétipos da mãe, representada pela deusa Danann; da inspiradora, como Brighid; da Rainha, expressa na deusa Macha; da velha sábia, simbolizada por Cailleach; e da grande transmutadora, que vemos em 
Cerridwen, falam à alma feminina e apontam para a jornada de reencontro com o Self.

\section{As deusas ancestrais celtas}

Antes de apresentar a história mítica de cada deusa, é importante ressaltar alguns pontos. $O$ primeiro é que pode ser um tanto limitante definir as deusas como "celtas", pois celtas, na realidade, foram os povos que as cultuavam entre o primeiro milênio a.C. e o primeiro século d.C., quando se expandiram pela Europa Ocidental. Sabe-se que as ilhas, como a Escócia, Inglaterra e Irlanda, passaram por várias ocupações culturais ao longo da história. A partir disso, por meio de estudos da arqueologia, história e mitologia, sabe-se também que boa parte das divindades cultuadas pelos celtas é bem anterior a eles, absorvidas e ressignificadas em seu culto ao longo do tempo, resultado das interações entre as culturas autóctones e indo-europeias.

O segundo ponto é que utiliza-se neste estudo a expressão "deusas celtas" com finalidade didática ou objetiva, como uma maneira de compreender melhor tais deidades e o ramo cultural em que estão relacionadas. Contudo, esclarecemos que é preferível denominá-las "apenas" como deusas, sem limitar esses arquétipos e sua profundidade a uma cultura ou tempo histórico. Portanto, seguiremos para conhecer a primeira deusa: Danann.

\section{Dannan: a mãe antiga}

Dannan é a deusa mãe dos povos célticos da Irlanda - e possivelmente também de Gales, onde encontramos uma deusa ancestral chamada Dôn, sobre a qual os mitos medievais pouco falam. Curiosamente há poucas referências à deusa Dannan nas lendas célticas, uma vez que ela é definida como a mãe dos deuses e dos homens. Estudiosos e celtistas afirmam que por ser a divindade mais antiga, seus mitos originais não foram registrados pelos monges irlandeses copistas do século XII, período em que vários mitos gaélicos estavam sendo repassados da tradição oral para a escrita.

Cristianismo, como religião oficial, estabelecia-se em praticamente toda a Europa, começava a reger a nova sociedade e seria uma heresia registrar uma antiga deusa mãe. As outras divindades antigas da mitologia céltica, como Manannan, Dagda e Morrigan, eram retratadas nas histórias não como deidades, mas como reis, rainhas ou personagens mágicos de tempos de outrora (Squire, 2003). Apesar disso, o espírito antigo céltico sobrevivia no imaginário e no folclore do povo. É nesse ambiente, das lendas contadas nos vilarejos e ilhas de pescadores, que encontramos as muitas histórias de Danann.

Ela é chamada por vários nomes, além de Danann, de onde as tribos ou filhos de Danann, em gaélico "Tuatha Dé Danann", a terceira raça divina que povoou a Irlanda, nasceu. Ana, Anu, Danu ou "Old Annie", a velha Annie, são nomes pelas quais a "mãe antiga" é conhecida na llha Esmeralda, como 
a Irlanda é chamada, em razão da sua cor verde pulsante, quando avistada do alto.

As montanhas que levam seu nome - chamadas em inglês de "Paps of Ana" e na língua gaélica, de "Dá Chich Anann", que pode ser traduzido como "os seios de Anann" - revelam sua principal história mítica. Trata-se de um mito recontado e resumido aqui a partir de estudos e leituras de várias fontes, sobretudo o folclore e a tradição oral.

Danann era uma mulher muito sábia entre seu povo, que habitava as ilhas ao norte do mundo'. Um dia, sonhou com um lugar muito bonito, repleto de rios e de montanhas. A terra neste lugar brilhava em uma cor verde-esmeralda e Dannan viu que ali era onde seu povo deveria habitar e deixar seu legado para as civilizações posteriores. Seguiram viagem pelo grande rio, que mais tarde ficou conhecido como Danúbio, até chegarem finalmente à llha Esmeralda. À medida que iam adentrando e habitando a ilha, rios, montanhas e florestas nasciam, pois eles tinham conhecimento sobre magia e com seu poder criavam as condições naturais na nova terra.

A viagem foi longa e muito trabalho foi feito na ilha que agora era seu lar, Danann já estava cansada e muito velha. Ela convocou seu povo, deu-lhes suas últimas instruções, cantou e abençoou seus filhos e filhas. Antes de deitar e dormir seu último sono, afirmou que para sempre iria nutrir e guiar seu povo naquela terra, em todas as eras. Ao se deitar, seu corpo uniu-se à terra e, no lugar de seus seios, duas montanhas surgiram, para que todos lembrassem da grande Danann e de seus ensinamentos.

Por muito tempo o povo de Danann viveu em paz na ilha. Até que um dia, chegaram os filhos de Mil, também chamados de milésios, provindos da Torre de Bréogan, na antiga Ibéria. Grandes batalhas aconteceram entre eles até que o druida dos milésios, Amergin, provou grande sabedoria ao honrar a alma da Terra, declamando um mágico poema à ilha da Irlanda. Dessa forma, os milésios conseguiram permissão para entrar na ilha e o povo de Danann aceitou que era o fim de sua era sobre a terra. Transformaram-se, segundo a lenda, nas fadas e seres encantados que habitam o submundo; o interior das colinas, os lagos e os bosques passaram a ser sua morada. Hoje, eles são chamados de "sídhe" ou "daoine sídh" - o povo bom (Squire, 2003; Bellingham, 1997).

A deusa Danann também tem relação com Aíne, a rainha das fadas. A montanha de KcnockAine, em Munster, na Irlanda, lhe é consagrada. Contam as lendas que na noite do solstício de verão, no dia 21 de junho, ela é vista no alto da colina, cavalgando seu corcel branco. Os muitos nomes e aspectos de Danann nos revelam a complexidade que sonda os mitos desta deusa, talvez uma relação com a própria complexidade da alma feminina.

${ }^{1}$ Outras versões dizem que este povo habitava os pontos meridionais do globo terrestre, quatro ilhas mágicas de onde aprenderam a arte da magia e a sabedoria da natureza. O que se pode afirmar é que trata-se de um lugar mítico, entre-mundos, ou no "Outro Mundo", de onde vêm os deuses e os seres mágicos. 
Danann, como vimos, é a mãe dos deuses e dos homens e simboliza o princípio feminino que gera e nutre, assim como a Terra, a natureza, semelhante a Démeter dos gregos. Ela é a sabedoria que guia o seu povo, a fertilidade e a magia da terra em sua profusão de ambientes e fenômenos naturais. $\bigcirc$ mistério da vida que morre e renasce em outras formas.

\section{Brighid: a chama da inspiração}

Brighid é também conhecida como Brigit, Bríd, na Escócia, ou ainda, Brigindu ou Brigantia na Gália, região da antiga França. Talvez tenha sido a deusa mais cultuada pelos povos celtas e galo-romanos, durante o primeiro século d.C. Há indícios de um forte sincretismo religioso no período galo-romano entre Brighid e Minerva e, posteriormente, com o advento do cristianismo, entre Brighid e santa Brígida na Irlanda. É no condado de Kildare que fica a catedral de santa Brígida, onde uma chama sagrada é mantida acesa pela Ordem das Irmãs Brigidinianas.

Brighid é uma deusa ligada profundamente à primavera e ao renascimento da terra. Na Escócia, é conhecida como Bríde, a rainha da primavera, enquanto que Beira, como é chamada Cailleach, é a rainha do inverno. Ambas disputam o amor do jovem Deus-Sol, Áengus.

Em algumas versões do mito elas são faces da mesma divindade, simbolizando a luz e a sombra, verão e inverno, dia e noite (Mackenzie, 1917). Cada uma reina em uma parte do ano: Bríde/Brighid reina durante a primavera e o verão, ou seja, de março a setembro no Hemisfério Norte; e Beira/Cailleach reina durante o outono e o inverno, de setembro a fevereiro. Brighid é representada como uma bela mulher, a natureza em seu esplendor e graça, enquanto Cailleach é vista como uma mulher muito velha, ora ranzinza e mal humorada, ora serena e bondosa.

A tradição oral irlandesa nos conta que Brighid nasceu no dia $1^{\circ}$ de fevereiro, no prenúncio da primavera. Sua face era brilhante e bela, como ninguém havia visto antes, e seu cabelo como uma labareda de fogo. A casa onde nasceu, ardeu em chamas diante de tanta luz, e quem avistava de longe pensava que havia dois sóis no céu, o sol de sempre que nasce no leste e um "sol" ardente sobre a casa de Brighid.

Como senhora do fogo sagrado, Brighid apresenta três faces ou aspectos: deusa do fogo da lareira, protetora das mulheres e do lar; deusa do fogo da forja, protetora dos guerreiros e ferreiros; e deusa do fogo da inspiração, protetora dos druidas e bardos, os poetas da antiga tradição. Ela é também senhora das fontes de águas sagradas que concedem o dom da cura e a fertilidade a quem delas beber. A fonte localizada em Kildare recebe milhares de visitantes e devotos, tanto da deusa como da santa, especialmente no dia $1^{\circ}$ de fevereiro, quando acontece o festival de "Imbolc" dedicado a ela e que marca o prenúncio da primavera.

Há algumas histórias de Brighid que a retratam como uma mulher sábia, convocada em situações de conflito e disputas. Ela aparece como uma espécie 
de "juíza" que traz a decisão ou a punição justa para cada caso. $\bigcirc$ provérbio popular que diz que "não se deve brincar com fogo" possivelmente tem relação com esse arquétipo. $\bigcirc$ fogo, elemento sagrado da deusa Brighid, clareia, ilumina, inspira, mas também queima, se não tivermos sabedoria e cuidado com ele.

A relação dessa deusa com o feminino é mais profunda e sugere a ligação com mistérios e magia. Antes de surgir a Ordem das Irmãs Brigidinianas, antigas lendas contam que o fogo sagrado de Brighid era guardado em seu templo por 19 sacerdotisas, por 19 dias, sendo que, no vigésimo dia, quem o mantinha era a própria deusa. Entre os gauleses, celtas que habitavam a região da antiga França, as "Matres Brigaecae", ou seja, as "Mães Elevadas", foram cultuadas como deusas triplas: da fertilidade, prosperidade e maternidade, representadas na iconografia galo-romana como três mulheres sentadas com vestes nobres, que seguram frutas, pães, pergaminhos ou bebês (Clann Bhríde, 2013).

Nas ilhas e vilarejos irlandeses, ela auxilia as mulheres durante o trabalho de parto. Uma tradição entre as parteiras era abrir a porta principal da casa e chamar por Brighid no momento em que se percebesse que a criança estava prestes a nascer, indicando que é esta deusa que traz a alma da criança para o mundo.

Brighid é uma deusa com múltiplos poderes e dons, ligada ao fogo, à água e à terra e, dessa forma, aos Três Mundos na cosmovisão céltica (céu, mar e terra). Uma deusa "exaltada", "elevada", como a origem de seu próprio nome diz. Uma grande deusa, sem dúvida.

\section{Macha: a deusa rainha}

Macha é a deusa ancestral celta da soberania, do poder feminino e da força da Terra. Está relacionada à fertilidade, ao ciclo da vida-morte-vida, e seus animais sagrados são o corvo e, especialmente, o cavalo. Sua principal história mítica é contada a seguir.

Havia um chefe tribal da região de Ulster, norte da Irlanda, chamado Crunniuc, que era viúvo e há muito tempo estava só e triste. Um belo dia chegou à sua casa uma mulher forasteira, muito bela, bem vestida e com aura de nobreza. Sem dizer quase nada, ela entrou, colocou ordem nos aposentos, nos serviços dos empregados e trouxe harmonia para o lar. Essa estranha e fascinante mulher conquistou o coração de Crunniuc e ele voltou a sentir alegria de viver. Ela correspondia ao seu amor e não lhe pedia nada em troca, apenas que a honrasse e que guardasse segredo sobre sua verdadeira natureza: que era uma mulher dos Sídhe, do "Outro Mundo". O chefe concordou feliz.

Tempos passaram e eles viviam contentes e em paz, mas algumas pessoas da vila sentiam estranhamento e medo diante daquela mulher. Embora sempre tratasse todos bem e fosse gentil, ninguém sabia de onde ela vinha, como havia chegado ali ou mesmo o seu verdadeiro nome. Boatos dos mais 
estranhos circulavam sobre ela: bruxa, feiticeira, fada, rainha? Ninguém sabia quem ela era, mas ainda assim mantinham-lhe certo respeito.

Com o tempo, um fruto do amor foi gerado, a mulher estava grávida e logo daria à luz. Era também época de um grande festival, quando várias tribos e clãs do Ulster reuniam-se para celebrar, fazer acordos, feiras, competições, entre as quais a mais esperada era a corrida de cavalos. Crunniuc não podia deixar de ir: como um chefe, ele tinha que estar presente. Antes de partir, a mulher o aconselhou que não exagerasse na bebida, pois temia que ele dissesse coisas que não deveria dizer. Com um beijo e uma benção eles se despediram. Tão logo ele partiu, a mulher começou a sentir os primeiros sinais do parto e recolheu-se em sua casa para ter a criança.

Crunniuc divertia-se no festival, conversava, bebia, e bebia bastante, esquecendo-se do conselho de sua mulher. No auge do festival, deu-se a corrida de cavalos. Todos aglomeraram-se animados para ver os melhores cavalos e seus cavaleiros disputarem. $O$ cavalo do grande rei e seu cavaleiro eram os mais fortes e muitos apostavam que eles iriam vencer; no entanto, Crunniuc não se conteve e lançou uma arriscada aposta. Falou para todos ouvirem: "Eu aposto que minha mulher corre mais do que qualquer cavalo de toda a terra de Ériu! Mais até do que o cavalo do rei!".

Todos silenciaram diante daquela aposta que era quase uma afronta ao rei. Este então disse: "Prove, então! Traga sua mulher para correr com os cavalos e veremos! Cumpra o que diz, se não pagará com a vida pela afronta a mim dirigida."

Prontamente, servos do rei partiram em disparada à casa de Crunniuc, para buscar sua mulher. Quando a encontraram e the explicaram o que havia acontecido, suplicou aos homens: "Por favor, tenham piedade. Estou com muitas dores e minha criança logo irá nascer". Mas eles insistiram, dizendo que se ela não fosse, seu marido iria morrer. Contrariada, ela foi. Ao chegar no local, a mulher foi colocada diante do rei e novamente suplicou: "Por favor, tenha piedade. Como vê estou prestes a ter minha criança, sinto muitas dores, não tenho condição de correr agora. Mas, dou minha palavra que depois que me recuperar do parto cumpro o que the foi prometido". O rei recusou e a obrigou a correr, caso quisesse salvar seu marido. Ela recorreu uma última vez aos homens, às mulheres e crianças que assistiam ao evento: "Por favor, eu peço piedade! Lembrem-se que todos vocês vieram de uma mãe, que passou pelo que estou passando agora. Deixem-me ter minha criança em paz, eu suplico!", falou, enquanto chorava e sentia as dores do parto cada vez mais fortes. Porém, ninguém atendeu ao seu pedido.

Sentindo-se sem saída, a mulher foi obrigada a correr com os cavalos. O rei deu a largada e todos saíram em disparada. A mulher, mesmo em desvantagem e cansada, correu o mais rápido que pôde e, para o espanto de todos, venceu!

No alto de uma colina e rodeada pelos cavalos, a mulher quase sem forças deu o grito que trouxe seus filhos gêmeos ao mundo. $\bigcirc$ grito pôde ser 
escutado por toda a Irlanda. As pessoas que ali estavam ficaram assustadas e fascinadas pela força daquela mulher. Enquanto a observavam em espanto, a mulher levantou-se com os bebês no colo e disse a todos: "Pela desonra que me fizeram sofrer, deste dia em diante durante cinco dias e cinco noites por nove gerações, eu condeno todos os homens do Ulster, no momento em que mais precisarem de suas forças, a sentirem as dores do meu parto!".

No meio da multidão assustada um homem perguntou: "Quem é você mulher?". E ela respondeu: "Eu Sou Macha! E para sempre este lugar terá o meu nome!".

E assim aquela colina foi chamada desde então de "Emain Macha", que significa "os gêmeos de Macha". Após dizer aquelas palavras, a mulher desapareceu e nunca mais foi vista. Crunniuc caiu em profundo arrependimento e desgraça, e todas as pessoas dali jamais lhe esqueceram.

Em outra história, possivelmente mais antiga do que essa, Macha aparece como esposa de Nemhedh, o rei da terceira raça que habitou a Irlanda, antes das "Tuatha Dé Dannan". Ela é representada como uma deusa visionária e profetisa, e teria "morrido" em uma das doze planícies pertencentes ao seu marido, chamada de "Ard Mach", Alta Planície de Macha. Em outro momento, aparece em uma narrativa como filha de Red Hugh e é uma rainha guerreira, governante de toda a Irlanda por um tempo. Mas, depois que seu pai morreu, seus dois irmãos teriam contestado sua soberania e iniciado uma disputa contra ela.

Macha apresenta atributos de rainha e de guerreira, ligada à magia e à sexualidade. Citada também nos mitos irlandeses como uma das irmãs ou aspectos de Morrighan, a Grande Deusa da Guerra e Magia. Chamadas também de "As Morriganas", que são Macha, Badb e Nemain, todas associadas ao corvo, à morte, à vida e à conexão com o "Outro Mundo".

Segundo Monika von Koss (2011), psicoterapeuta e estudiosa dos mitos e arquétipos do feminino:

A Deusa como Soberania é parte intrínseca do mundo celta. Ela não é um símbolo nem uma abstração, mas a própria terra abaixo dos nossos pés, o próprio poder soberano da vida, razão pela qual foi uma das imagens mais difíceis para a cultura ocidental erradicar, a visão de mundo patriarcal tornando-se possível apenas pelo desmembramento do ciclo natural de vida e morte (p.1).

A história mítica dessa deusa é uma das mais emblemáticas, pois se observa que esse mito retrata, entre outras coisas, o período em que a sociedade céltica passava pela transição de uma cultura centrada no princípio feminino para uma cultura pautada em valores patriarcais, onde tudo que era referente ao feminino começava a ser subvalorizado.

Na história acima resumida, vemos que Macha suplica por respeito e dignidade diante dos homens do Ulster, mas é humilhada e sua soberania desonrada. Ato, porém, que não fica impune. Macha recorda-se de seu poder, 
assume sua forma de deusa, lançando sua raiva sobre os homens que a desonraram, e conjura uma maldição sobre eles que, no fim, mostra-se uma grande lição. Para que todos, inclusive ela mesma, relembrem do poder do princípio feminino e recordem, afinal, que todos viemos de um ventre e retornaremos a ele um dia: ao ventre da Terra, que é a própria deusa nessa cosmovisão.

\section{Cailleach: a velha sábia}

Cailleach é outra deusa ancestral das terras célticas. Sua origem possivelmente é anterior à chegada dos indo-europeus nas ilhas. Ela foi reverenciada na Irlanda, Escócia e também Galícia, localizada na Península lbérica, cujo nome antigo era Callaecia, indicando aproximação com o nome dessa deidade. "Cailleach" ou "Cailligh", do gaélico, quer dizer "velha esposa" ou "aquela que é velada". É conhecida como filha de Grianan, o pequeno sol ou o sol do inverno, confirmando sua relação com a estação invernal (Prieto, 2017).

Na Escócia, é chamada de Beira, a Rainha do Inverno, representada como uma deusa gigante que veste um manto cinza e que salta de uma montanha a outra, provocando tempestades e granizo. Na Irlanda, a "Cailleach Bheur" possui um bastão que quando toca a terra congela o solo e provoca os trovões nas tempestades. Ela é chamada muitas vezes apenas de "The Hag", "A Bruxa", acompanhada de sua cabra e de suas ajudantes, outras feiticeiras.

Por vezes, considerada uma figura tenebrosa, de pele azulada, dentes afiados e um olho na testa, que espalha o frio e a morte no inverno, ela também pode ser vista como uma velha simpática, que caminha entre as montanhas e protege os animais e os mais vulneráveis, como crianças e idosos, durante as longas noites frias da estação. Muitas lendas e mitos são encontrados sobre esta deusa no folclore e na tradição oral. Uma delas conta que ela foi responsável pelo surgimento de várias montanhas e lagos na Irlanda, estando presente, portanto, desde a formação da Terra.

Um antigo conto diz que carregava em seu avental pedras para construir sua casa e ao saltar de uma montanha para outra tropeçou, deixando cair todas as pedras que trazia consigo. Ali se formou o monte de pedras de Loughcrew, conhecido em gaélico como "Sliabh na Cailligh", "Colina" ou "Castelo de Cailligh". Trata-se de um complexo neolítico, construído há mais de cinco mil anos pelas civilizações pré-célticas, alinhado aos equinócios da primavera e do outono, que ocorrem próximos a 21 de março e a 21 de setembro no Hemisfério Norte, quando, no amanhecer destas datas, o primeiro raio de sol ilumina a câmara central do complexo (Malone, 2010).

Nos mitos escoceses (Mackenzie, 1917), Cailleach/Beira mantém a donzela Bríde como prisioneira em seu castelo de gelo e a trata como uma escrava. Porém, um de seus filhos ${ }^{2}$, o belo jovem Áengus, apaixona-se por Bríde e a

${ }^{2}$ As lendas e mitos antigos da região contam que Cailleach teve muitos filhos, entre gigantes titânicos e belos deuses. 
ajuda a escapar do domínio de sua mãe. Cailleach e Bríde fazem uma longa batalha e perseguição até que a donzela da primavera escapa da prisão de gelo e casa-se com o deus solar Áengus. Nesse momento, Cailleach perde seu reinado e Bríde toma o seu bastão, tornando-se então rainha.

Em outra versão do mito, Cailleach percorre a terra espalhando frio e gelo durante o inverno. Depois de muito andar, fica extremamente cansada, tão cansada e velha, que se recolhe às Ilhas Abençoadas do Oeste. Lá, encontra uma fonte mágica que guarda a água com o poder de rejuvenescer. Cailleach então bebe a água e torna-se bela e jovem novamente, passando a se chamar Bríde, palavra que tem a mesma raiz de "bride" no inglês e significa noiva. Revigorada, a deusa retorna a terra e reina como a Rainha da Primavera, casa-se com o deus-sol e desperta a natureza depois do longo inverno.

Cailleach representa a força da noite, da escuridão e do inverno, que apesar de tudo, guarda a semente da primavera, tal como Bríde é mantida no castelo de gelo. O período do inverno nos países célticos é geralmente duro e difícil, o frio é cortante e tenebroso. Mas pode ser também um momento de aproximar a família ao redor do fogo, reforçar os laços e relembrar a sabedoria dos antepassados.

A "Velha Sábia" conhece o mundo desde a sua formação, ela mesma teria criado algumas montanhas e lagos. Sabe onde fica a fonte da juventude e conhece os segredos da imortalidade. Sabe como tornar-se jovem e bela e, ainda assim, guardar a sabedoria de tantas eras.

\section{Cerridwen: senhora da transformação}

Em toda a mitologia celta conhecida, essa deusa é a única que aparece, explicitamente, sendo dona ou portadora de um caldeirão mágico. Em outros mitos, este objeto está sob o domínio de deuses masculinos, como Dagda, que possui o "caldeirão da abundância", cujo poder é fornecer alimento em abundância, sem nunca se esgotar, e Bran, com o seu "caldeirão do renascimento", onde ele coloca os guerreiros mortos em batalha e estes renascem ilesos, porém, perdem a capacidade da fala. Interessante observar que o caldeirão, cálice, taça ou vaso são importantes símbolos do útero da mulher, matriz da vida (Espírito Santo, 2010), no entanto, na maioria dos mitos celtas, estes objetos estão na posse de deuses e não deusas. A exceção é Cerridwen, deusa cultuada no País de Gales e ligada à sabedoria, à inspiração, à iniciação bárdica e à transformação.

Não sabemos afirmar a razão dos deuses possuírem esses caldeirões, originados sem dúvida no mesmo arquétipo. Talvez algum mito tenha se perdido na história, um mito que contasse como esses deuses adquiriram, ganharam ou roubaram o mágico caldeirão. Ou talvez isso represente mais um indício da transição para o paradigma do patriarcado, em que os princípios femininos da vida e da transformação foram transfigurados na imagem do caldeirão, que passou ao domínio do masculino. Para além dessas suposições, o fato é que Cerridwen permaneceu na mitologia céltica como a 
"Senhora do Caldeirão" da Awen, palavra galesa traduzida como inspiração divina.

O principal mito de Cerridwen conta que ela é uma rainha de Gales, mãe de dois filhos, uma menina muito bela, chamada Creirwy, e um menino muito feio, Afagddu. Para compensar a extrema feiura do filho, Cerridwen decide preparar uma mágica poção em seu caldeirão que proporciona, a quem dela beber, os dons da sabedoria e da inspiração. Porém, não é uma poção simples de fazer, é preciso colher ingredientes e ervas especiais, conhecidos apenas por ela, em momentos específicos do ano, e ferver em fogo brando, nem alto nem baixo, durante o ciclo de um ano e um dia.

Para ajudá-la nessa tarefa, a deusa contrata um antigo servo cego, chamado Morda, que ficou encarregado de alimentar o fogo com a madeira, para que ele não se apague, e um garoto chamado Gwion, responsável por mexer a poção sem parar. Cerridwen ordena que ninguém toque ou beba a poção, pois ela era destinada ao seu filho.

Estava quase terminando o período de preparo da poção, que fervia em fogo brando, durante dias e noites ininterruptos, quando o líquido borbulhou e três gotas pularam direto no dedo de Gwion. Sentindo a dor da queimadura, ele instintivamente levou o dedo à boca e bebeu as três gotas que continham a sabedoria. Nesse instante, Gwion conheceu os mistérios da natureza e entendeu coisas inexplicáveis sobre o passado, o presente e o futuro. Ele soube também que Cerridwen ficaria furiosa e, com receio de ser castigado, fugiu. Na fuga, esbarrou no caldeirão que caiu e partiu-se em dois, derramando o restante da poção. Apenas as três gotas eram mágicas, o restante tornou-se veneno, que se espalhou em um lago próximo dali e envenenou a água, os peixes e os cavalos que bebiam dela. Cerridwen vendo o que tinha acontecido saiu em perseguição a Gwion.

Ela o perseguiu por terra, mar e céu. Gwion, que agora tinha um conhecimento mágico, podia se transformar em tudo. Primeiro, ele transformou-se em uma lebre, mas Cerridwen transformou-se em um cão de caça e o perseguiu. Gwion pulou em um rio e tornou-se um salmão, enquanto Cerridwen virou uma lontra e continuou perseguindo-o. Saltando da água, ele virou um pássaro e ela assumiu a forma de um falcão. Voando como um pássaro, Gwion avistou um monte de feno e grãos de trigo em um celeiro e se lançou no monte, transformando-se em um pequeno grão. Por fim, Cerridwen transformou-se em uma galinha negra e o engoliu.

A deusa retorna a sua forma original e percebe naquele momento que estava grávida. Nove meses depois, dá a luz um lindo menino, que era o próprio Gwion renascido. Ela desiste de castigá-lo e o embrulha em uma bolsa de couro, lançando-o ao mar. Três dias depois em Beltane, no dia $1^{\circ}$ de maio (que marca um festival sagrado entre os celtas), um príncipe, não muito afortunado segundo as lendas, chamado Elphin, encontra o bebê em uma represa e resolve criá-lo junto com sua esposa. Ele chama o bebê de Taliesin, que quer dizer "semblante radiante". 
O bebê apresenta um crescimento rápido, mais rápido do que o normal entre as outras crianças, e habilidades especiais, como declamar poemas, realizar encantamentos e cantar de forma divinamente inspirada. Ele foi conhecido como o maior bardo de Gales, chamado também de Myrddin.

Caldeirão, como vemos, é tanto o objeto sagrado de Cerridwen quanto o seu próprio útero, de onde Gwion renasce e transforma-se em um grande sábio. Cerridwen, apesar de ser a Senhora da Awen e da sabedoria, não pôde prever que Gwion tomaria a poção. Porém, caso ela tenha previsto, será que a caçada mágica não passou de um jogo da deusa? Parte da iniciação bárdica que Gwion, seu filho afinal, deveria passar? Podemos dizer que há conhecimentos que estão para além do controle. Cerridwen é o mistério em si, até para ela mesma.

O mar que Taliesin recém-nascido atravessa é um elemento mítico do grande mistério, imagem arquetípica da origem da vida. É pelo mar ou pela água que chega-se ao mundo material, e é por ele também que retorna-se ao mundo espiritual, segundo o imaginário e a mitologia celta (Barros, 1994).

Essa deusa, portanto, nos fala sobre o mistério que é a vida, eterno ciclo de transformações. $\bigcirc$ mito de Cerridwen e Taliesin guarda múltiplos significados e perspectivas, sobre os quais não há espaço suficiente para explanar neste artigo.

Como aconteceu com Gwion, por mais que tentemos fugir, a sabedoria e o mistério da vida estão em nosso percalço e uma hora nos alcançarão e nos engolirão. Ela nos transforma e nos devolve a uma nova existência. Aí está a chave do mito de Cerridwen, ou uma das tantas que existem.

Cada deusa aqui apresentada fala de símbolos muito profundos e traz em sua história uma jornada em si, jornadas estas que são tecidas e interligadas umas nas outras. Mesmo sem analisar de forma extensa cada mito, podemos acessar em vários níveis os arquétipos neles representados, bem como insights que são despertados com a leitura e reflexão dessas narrativas. A partir de estudos profundos sobre a mitologia celta, percebemos que essas cinco deusas representam imagens arquetípicas muito antigas, que deram origem possivelmente a outras deidades desse panteão.

A seguir, vamos apresentar como a jornada dessas deusas conecta-se com a jornada da alma feminina.

\section{A jornada da alma feminina}

Por longo tempo, o feminino foi bastante fragmentado, sufocado e subjugado pelas culturas patriarcais, que reprimiram e adoeceram a psique de mulheres e de homens também. O movimento que vem surgindo nos últimos anos busca resgatar, reintegrar e reafirmar a relação saudável com o feminino e o masculino ancestral. Para isso, parte essencial desse processo é a restauração na alma do feminino sagrado. Nas mulheres, a conexão com a "mulher selvagem", com sua natureza essencial ou deusa interior, como algumas 
autoras denominam (Estés, 1997; Penna, 1993), deve ser restabelecida para que sua cura aconteça. De acordo com Estés (1997):

O arquétipo da Mulher Selvagem envolve o ser alfa matrilinear. [...] Ela também chega a nós através dos sons; da música que faz vibrar o esterno e que anima o coração. Ela chega com o tambor, o assovio, o chamado e o grito. Ela vem com a palavra escrita e falada. Às vezes uma palavra, uma frase, um poema ou uma história soa tão bem, soa tão perfeito que faz com que nos lembremos, pelo menos por um instante, da substância da qual somos feitas e do lugar que é o nosso verdadeiro lar. [...] Uma vez que as mulheres a tenham perdido e a tenham recuperado, elas lutarão com garra para mantê-la, pois com ela suas vidas criativas florescem; seus relacionamentos adquirem significado, profundidade e saúde; seus ciclos de sexualidade, criatividade, trabalho e diversão são restabelecidos (p. 20-21).

Durante muito tempo, poucos cientistas reconheceram a presença e a relevância do arquétipo do feminino. Da história à psicologia, o feminino e, especificamente, as culturas matrifocais tiveram sua existência questionada em muitas teorias. Entretanto, observa-se a preponderância e a substancial existência dessas tradições ao longo das eras. De acordo com o historiador e celtista Jean Markale (1997):

Devemos dizer que a "história das religiões" se desenvolve cada vez mais a favor das novas descobertas arqueológicas ou linguísticas e que, com muita frequência, esses historiadores se apercebem com estupefacção [sic] de que a Grande Deusa dos tempos antigos nunca deixou de falar aos humanos a linguagem de uma eterna feminidade. E essa linguagem é acessível a todos: o seu teor afetivo dispensa-o de toda a consideração de ordem lógica (p. 49).

As deusas aqui apresentadas falam sobre aspectos profundos da alma feminina. Cada mito é uma jornada em si, que está dentro de outra jornada ainda maior: o reencontro consigo, o Self.

O mito de Danann traz a cura da relação com mãe, pois sabemos que muitos complexos surgem na infância e idades seguintes. Honrando a origem da vida, independentemente de como ela se apresentou para cada pessoa, é o começo da cura e início da jornada. Trata-se de entender que muitas vezes nossas mães ou cuidadoras repetem padrões inconscientes, aprendidos em gerações, e que é necessário tomar consciência sobre eles, romper com o ciclo vicioso e criar um novo ciclo virtuoso.

Dannan nos ensina a ouvir a voz do feminino, manifestada na terra e em toda a natureza, já que ela se torna a própria Terra na história. Ela guia o seu povo até encontrar a "terra prometida", a llha Esmeralda, simbolizando o lar primeiro da alma. Ela instiga seu povo a iniciar a jornada nessa busca e, ao 
final, transmuta-se na terra verdejante e fértil, para continuar nutrindo e guiando sua tribo.

Com Brighid, trazemos a luz e a chama de nosso fogo à vida novamente. Seu arquétipo é aquele que desperta a inspiração, o ânimo, a energia de criar e alimentar nossos sonhos. Um sintoma observado nos quadros de depressão é justamente a profunda falta de ânimo nos indivíduos, que parecem estar realmente com sua "chama apagada" ou quase se extinguindo. $\bigcirc$ alto índice de mulheres com depressão ou profundo desânimo é um dos sintomas do quanto o feminino precisa ser resgatado e curado em cada mulher, e na sociedade como um todo.

Brighid é a deusa que reacende essa chama da vida, aquela que inspira a seguir adiante na jornada, levando sua luz a todo canto que esteja. $\bigcirc$ fogo, como elemento místico, também representa a paixão, no sentido de paixão e amor pela vida, por alguém, por um projeto, por sonho e, sobretudo, por si mesma.

Macha chama as mulheres para retomarem sua soberania, seu poder pessoal, afirmando-se na jornada de suas vidas. Muitas mulheres se esquecem de suas identidades, desconectam-se de seu Self, sua "mulher selvagem", quando passam por períodos de grande dor, como uma perda, um relacionamento abusivo ou uma violência. São mulheres que têm seu feminino profundamente ferido e precisam relembrar de sua força, de seu potencial de cura e de realização. Macha reflete o arquétipo da deusa-rainha, da mulher senhora de si, de suas escolhas e vida. Aquela que é honrada pelos outros, pois honra a si mesma.

A sociedade patriarcal pretendeu destituir o poder do feminino, mas este não pode ser destituído, pois ele é o princípio da vida. As mulheres possuem o dom de gerar vidas, independentemente de escolherem a maternidade ou não. Isso, por si só, é um grande poder. Nas culturas neolíticas e até a primeira fase da história dos celtas, constata-se que essas antigas tradições honravam esse princípio, mas ao longo do tempo o paradigma do patriarcado foi tomando espaço. E agora chegou o tempo em que o feminino ressurge, em que a "mulher selvagem" liberta-se das correntes e traz o vento da liberdade consigo.

Cailleach, expressando o arquétipo da velha sábia, representa a finalização dos ciclos e também a sabedoria antiga que se renova sempre. Diante da morte de alguém ou algo, como um relacionamento ou uma fase da vida, não há quem não tenha sentido medo ou a dor da perda. No entanto, faz parte da existência humana passar por essas experiências. Assim como a morte, Cailleach também instiga medo, mas traz consigo muita sabedoria. Ao mesmo tempo em que ela é a rainha do inverno, ela guarda a promessa da primavera. Da mesma forma, a morte guarda a semente de uma nova vida. Ter essa compreensão nos momentos de luto pode auxiliar no processo de recuperação. 
Como deusa que manifesta o arquétipo da velha sábia, Cailleach ensina a ter paciência diante dos ciclos da vida, compreendendo que há tempo para tudo - tempo para nascer, viver, morrer e renascer.

Por fim, a deusa Cerridwen reflete o arquétipo da transformação que se segue a cada fim de ciclo. Essa deusa preside a iniciação, não necessariamente no sentido místico ou espiritual, embora possa estar relacionado, mas no sentido humano e existencial. É a transformação que se dá em todos nós diante de um intenso processo de mudanças que se vivencia. Não é possível continuar sendo a mesma pessoa depois de encarar uma perda, uma doença ou uma grande mudança na vida. Essa transformação nem sempre é fácil e às vezes queremos fugir, como Gwion o fez no mito, ou negar, mas ela sempre acontece e tem como propósito a evolução, o crescimento e a expansão da consciência sobre si e sobre a própria vida.

Transformar-se exige deixar a forma anterior e assumir uma nova forma. Com isso, Cerridwen encarna o ciclo da vida-morte-vida, cujo caldeirão representa um lugar de extrema importância e significância dentro do mito, assim como seu útero, onde Gwion é gestado e renascido. Ela é a deusa velada, presente em outros antigos mitos. Com sua dança de eterno velar e desvelar, brinca com o próprio mistério e nos inspira a entrar nesta dança, que é a própria dança e o movimento do autoconhecimento, a jornada da alma.

\section{Considerações finais}

Ao longo dos últimos anos, este estudo desenvolve-se e estende-se desde minha vida pessoal à profissional. Com base nele, venho criando um trabalho denominado de "Ciranda das Deusas", cuja composição envolve danças, mitopoética, saberes femininos e outras abordagens do desenvolvimento humano.

As deusas que vimos expressam aspectos do que chamamos de arquétipo ou princípio feminino, que obviamente não pode ser limitado ou resumido em apenas cinco deusas. Da mesma forma, a análise e a interpretação apresentadas neste artigo não estão definitivamente concluídas, pois os símbolos refletem forças do inconsciente que estão em constante movimento e renovação. A jornada de cada deusa ressoa na alma das mulheres, embora saibamos que cada mulher é única, bem como a sua própria jornada de vida.

Espera-se que este estudo contribua com os campos da psicologia analítica e da fenomenologia da religião. $O$ estudo da mitologia e dos arquétipos é fascinante; mais ainda é o estudo sobre o arquétipo do feminino, cuja área de conhecimento é vasta e apresenta cada vez mais novas perspectivas.

Podemos dizer então que a jornada simbólica da alma feminina está centrada no reencontro com a sua soberania, o seu poder de cura, a inspiração, a transformação, a sabedoria e o amor para guiar a sua própria vida. E essa jornada segue, continua, como uma ciranda, sempre em movimento. 


\section{Referências}

Barros, M. N. A. (1994). Uma luz sobre Avallon. São Paulo: Mercuryo.

Bellingham, D. (1997). Mitología celta. Madrid: Edimat Libros.

Boff, L. (2014). Saber cuidar: a ética do humano. Petrópolis, RJ: Vozes.

Carr-Gomm, P. (s.d.). Elementos da tradição druida. Rio de Janeiro: Ediouro.

Clann Bhríde. (2013). O livro das horas: para práticas diárias e sazonais (M. Paschoalin, \& R. Seneween, trads.). [s.I.]: Autor. Recuperado em 20 de março de 2019, de http://caminhodotarot.com.br/wpcontent/uploads/2017/05/Livro-das-Horas-1.pdf.

Eliade, M. (2012). Sagrado e profano: a essência das religiões. São Paulo: Martins Fontes.

Espírito Santo, M. I. (2010). Vasos sagrados: mitos indígenas brasileiros e o encontro com o feminino. Rio de Janeiro: Rocco.

Estés, C. P. (1997). Mulheres que correm com os lobos: mitos e histórias do arquétipo da mulher selvagem. Rio de Janeiro: Rocco.

Jacobi, J. (2016). Complexo, arquétipo e símbolo: na psicologia de C. G. Jung. Petrópolis, RJ: Vozes.

Jung, C. G. (2016). O homem e seus símbolos. 3a edição esp. Rio de Janeiro: Harper Collins. (Trabalho original publicado em 1964).

von Koss, M. (2011). Soberania, a grande deusa celta. Recuperado em 25 de março de 2019, de https://medium.com/@koss.monika/soberania-agrande-deusa-celta-a95e2e71 ec96.

Launay, O. (1978). A civilização dos celtas. Rio de Janeiro: Otto Pierre Editores.

Mackenzie, D. A. (1917). Wonder tales from Scottish myth and legend. Scotland: [s.n.]. Recuperado em 20 de março de 2019, de http://www.sacred-texts.com/neu/celt/tsm/index.htm.

Malone, K. A. (2010). Discovering ancient ireland. Dublin: The History Press Ireland.

Markale, J. (1997). A grande deusa: mitos e santuários, da Vênus de Lespugue à Nossa Senhora de Lourdes. [Lisboa]: Instituto Piaget.

Nogueira, C. (2004). Bruxaria e história: as práticas mágicas no Ocidente cristão. [Florianópolis]: EDUSC.

Penna, L. (1993). Dance e recrie o mundo: a força criativa do ventre. São Paulo: Summus.

Prieto, C. (2017). Todas as deusas do mundo. São Paulo: Ed. Alfabeto.

Squire, C. (2003). Mitos e lendas celtas. São Paulo: Nova Era. 
Terrin, A. N. (1996). O arquétipo do feminino na história das religiões e no reavivamento da nova era. In Nova era: a religiosidade do pós-moderno (pp. 190-214). São Paulo: Loyola.

Minicurrículo: Mayra Cristina Silva Faro Cavalcante - Mestra e graduada em Ciências da Religião pela Universidade do Estado do Pará (UEPA). Especialista em Psicologia Analítica Junguiana (Faculdade Unyleya. Professora na disciplina de Ensino Religioso na rede municipal de Ananindeua/PA. Focalizadora de danças circulares sagradas e estudiosa da espiritualidade feminina. Belém/PA, Brasil.E-mail:mayrafaro@yahoo.com.br 